\title{
Tactile sensitivity of blind and visually impaired children and adolescents. The significance of swimming exercises
}

\author{
Elżbieta Rostkowska ${ }^{1}$ Elżbieta Maśnik ${ }^{2}$ \\ ${ }^{1}$ Department of Swimming and Life-saving, University School of Physical Education, \\ Droga Dębińska 12a, 61-555 Poznań, Poland \\ ${ }^{2}$ Department of Biology and Environmental Protection, University School of Physical \\ Education, Królowej Jadwigi 27/39, 61-871 Poznań
}

\begin{abstract}
The aim of the study is to compare the tactile sensitivity threshold (TST) of the blind children who practice swimming and those who do not practice any sports with the TST of healthy people of similar age. TST was measured on the pad of the index finger of the dominant hand using an aesthesiometer. Lower TST was found in blind girls compared to healthy girls as well as lower TST in blind girls who practice swimming compared to the blind girls who do not practice any sports. A significant lowering of the TST during exercises in water was noted.

KEY WORDS tactile sensitivity threshold, aesthesiometry, physical activity, swimming

Prz. Antropol. - Anthropol. Rev. (2001), vol. 64, pp. 101-108, Figs. 7, Tables 5. ISBN 83-86969-64-4, ISSN 0033-2003
\end{abstract}

\section{Introduction}

The sense of touch allows to obtain information about the outside material world, and at the same time enables humans to exert adequate, premeditated influence on the environment. A human body is equipped with the ability of immediate adaptation to various living conditions (adaptability). Adaptability with regard to perception enables the coshaping of perception states of an organism by conditions of the environ- ment in which it lives. The body's response is not always adequate to the set of environmental conditions or to a stimulus affecting the body. It depends on the sensitivity of the body to a given type of stimulus and its ability to undergo adaptive changes.

Empirical research on the degree of eco-sensitivity of touch was carried out by KOZŁOWSKA [1998a,b]. According to this author, the threshold of human tactile sensitivity may be affected by a number of factors of different back- 
grounds such as genetic (e.g., sex), developmental (age, body mass) and socioeconomic factors (material and occupational status, life style). External conditions such as air temperature, humidity and hydration of the skin surface also affect the changes in the tactile sensitivity threshold [BOLANOWSKI and VERRILLO 1982; ELSNER et al. 1994; VERRILLO et al. 1998].

High eco-sensitivity of tactile sensitivity and the large number of circumstances, which may modify it, provoked an attempt to search for its further relationships with other properties of the body and external environment. There is a belief that the loss of sight may be compensated by increased tactile sensitivity [LINDSAY and NORMAN 1984]. A blind person, or a person with significant sight loss, maintains his or her contact with the outside world by, among other things, perfecting the perception of stimuli other than visual ones.

There is also another similar situation in which the inability to use visual information forces a person to intensify perception of tactile stimuli. It is physical activity in water. A person immersed in water, a swimmer, receives from this environment information on water temperature, resistance, density, waving and other. Making a paddling movement with a limb a swimmer must give an appropriate motoric response which will make this movement adequate to water resistance and density and will move the body with an expected speed. Constant repetition of this activity in the course of a long-term regular swimming practice should bear the same effect as many years of extra-sensitive reception of stimuli from the outside world by the blind.

The purpose of this study is to find out whether tactile sensitivity thresholds of the blind and of the people with significant impairment of sight who practice swimming (physical exercise in water) differ from tactile sensitivity thresholds of the blind who do not practice swimming, and to compare the results obtained with the results for healthy people of similar age.

\section{Materials and methods}

The research material consisted of children and adolescents with total and significant loss of sight and healthy children and adolescents. Both groups were subdivided into swimmer and nonswimmer groups (Table 1).

The tactile sensitivity threshold (TST) was measured using an aesthesiometer on the pad of the index finger of the dominant hand. The measurement was taken from the dominant hand due to the fact that also in the symmetrical movement of a swimmer this hand achieves higher perfection of movement technique, thus affecting the water resistance

Table 1. Size of groups

\begin{tabular}{|c|c|c|c|c|c|c|c|c|}
\hline & \multicolumn{4}{|c|}{ Blind and visually impaired } & \multicolumn{4}{|c|}{ Healthy } \\
\hline & \multicolumn{2}{|c|}{ not practicing sports } & \multicolumn{2}{|c|}{ swimmers } & \multicolumn{2}{|c|}{ not practicing sports } & \multicolumn{2}{|c|}{ swimmers } \\
\hline & $\mathrm{N}$ & age & $\mathrm{N}$ & age & $\mathrm{N}$ & age & $\mathrm{N}$ & age \\
\hline Girls & 42 & $6-18$ & 13 & $11-15$ & 45 & $7-17$ & 60 & $8-15$ \\
\hline Boys & 37 & $7-21$ & 21 & $11-19$ & 35 & $8-15$ & 102 & $8-15$ \\
\hline Total & 79 & & 34 & & 80 & & 162 & \\
\hline
\end{tabular}


to a greater degree. Determination of the threshold of tactile sensitivity involved finding an aesthesiometer filament with the lowest possible pressure perceivable by the subject. The result of the aesthesiometer measurement is the value of pressure expressed in $\mathrm{g} / \mathrm{mm}^{2}$. The tactile threshold was measured three times: (1) before the start of the swimming exercise, i.e., the preliminary measurement (the so-called "dry measurement"), (2) after 10 minutes of swimming, (3) after 30 minutes of swimming. In groups which did not exercise in water only the "dry measurement" was performed.

Since the distributions of the trait under study in all groups and in subsequent measurements differed significantly from the normal distribution model, non-parametric tests were used in the statistical analysis.

\section{Results}

The description of the results is presented in Tables 2 and 3, and examples of the distribution of variation against the normal distribution model are shown in Figs. 1-3. In girls, a statistically significant difference was found between the results of the blind and the healthy the value of the Mann-Whitney $U$ test with $U=669.5 ; p<0.02$. Blind girls showed higher tactile sensitivity (lower sensitivity threshold) in comparison with healthy girls. No statistically significant difference between the healthy and blind (or visually impaired) boys was found.

Comparing the results of the measurements between girls and boys, only one statistically significant difference was found: blind, non-swimming boys

Table 2. Tactile sensitivity (TST) of swimmer subjects (measurements taken: 1 - before, $2-$ after 10 minutes, and 3 - after 30 minutes of swimming)

\begin{tabular}{lcccccc}
\hline Group & Measurement & Mean & Me & $\min -\max$ & $\mathrm{Q}_{1}$ & $\mathrm{Q}_{3}$ \\
\hline Healthy girls & 1 & 12.2 & 13.1 & $6.2-20.5$ & 10.5 & 13.1 \\
& 2 & 9.6 & 10.5 & $6.2-17.5$ & 6.2 & 10.5 \\
Healthy boys & 3 & 8.5 & 8.8 & $6.2-13.1$ & 6.2 & 10.5 \\
& 1 & 12.2 & 13.1 & $6.2-20.9$ & 10.5 & 13.1 \\
Blind girls & 2 & 9.6 & 10.5 & $6.2-20.5$ & 6.2 & 13.1 \\
& 3 & 9.2 & 8.8 & $6.2-17.5$ & 6.2 & 10.5 \\
Blind boys & 1 & 12.5 & 13.1 & $8.8-17.5$ & 10.5 & 13.1 \\
& 2 & 10.8 & 10.5 & $6.2-20.9$ & 8.8 & 10.5 \\
& 3 & 9.5 & 8.8 & $6.2-13.1$ & 8.8 & 10.5 \\
& 1 & 13.5 & 13.1 & $8.8-20.5$ & 10.5 & 17.5 \\
\end{tabular}

Table 3. Tactile sensitivity (TST) of not practicing sports subjects

\begin{tabular}{llccccc}
\hline Group & & Mean & Me & $\min -\max$ & $\mathrm{Q}_{1}$ & $\mathrm{Q}_{3}$ \\
\hline Healthy & girls & 10.8 & 10.5 & $6.2-17.5$ & 8.8 & 13.1 \\
& boys & 12.1 & 13.1 & $6.2-20.5$ & 8.8 & 13.1 \\
Blind & girls & 9.6 & 8.8 & $6.2-17.5$ & 8.8 & 10.5 \\
& boys & 13.9 & 13.1 & $6.2-20.9$ & 10.5 & 17.5 \\
\hline
\end{tabular}




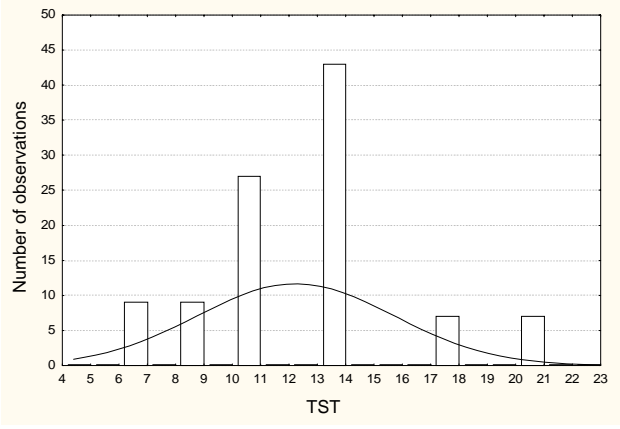

Fig. 1. Distribution of TST in healthy boys, swimmers (preliminary measurement).

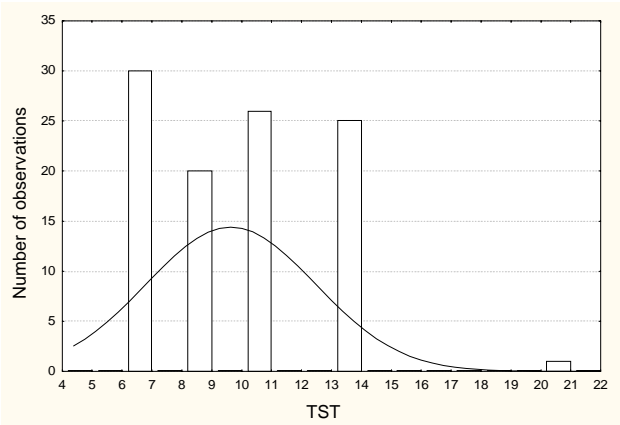

Fig. 2. Distribution of TST in healthy boys, swimmers (measurement taken after 10 minutes of swimming).

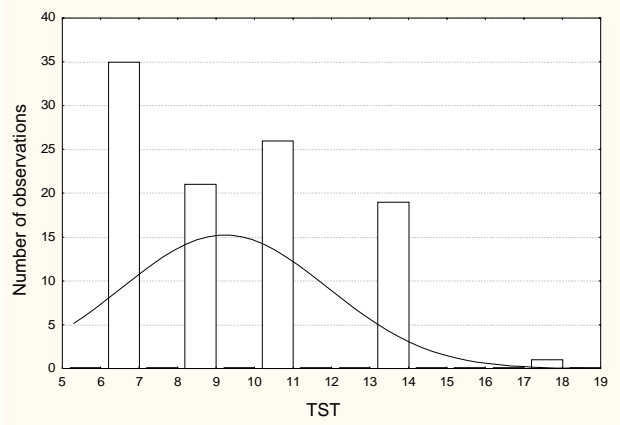

Fig. 3. Distribution of TST in healthy boys, swimmers (measurement taken after 30 minutes of swimming).

proved to show greater tactile sensitivity than girls from the corresponding group $(\mathrm{U}=333.0 ; \mathrm{p}<0.001)$. Similarly, the comparison between subgroups of swimmers and non-swimmers showed only one difference. Blind swimming girls turned out to be more tactilely sensitive than blind non-swimming girls $(\mathrm{U}=108.5 ; \mathrm{p}<0.001)$. The highest tactile sensitivity threshold was found in the groups of blind boys, both swimming ones and those who did not practice the sport, while the lowest threshold was noted in girls who did not practice swimming, both healthy and blind ones.

The subjects were also divided into subgroups according to the degree of their disability: (1) totally blind subjects, or those having only the sense of light, and (2) subjects with strong impairment of sight. No relationship was found between the degree of disability defined in this way and the level of the tactile sensitivity threshold. However, a correlation of tactile sensitivity with age was found. It turned out that the older the person, the higher the TST, i.e., the lower the sensitivity. The correlation was found in groups of blind, non-swimming girls and boys; healthy non-swimming girls; as well as in the group of healthy swimming girls and boys (Table 4).

The subjects who practiced swimming were examined in an indoor swimming pool, first before getting into the water, and then after 10 and 30 minutes of swimming. The results of the study presented in Figs. 4-7 indicate the lowering of the TST during exercise in water. A statistical analysis carried out using the ANOVA Friedman's test showed a statistically significant difference between subsequent measurements (Table 5; see also Figs. 1-3). The changes between the results of the preliminary measurement (1) and the measurement after 10 minutes of swimming (2) were more distinct 
Table 4. Statistically significant correlation between age and TST

\begin{tabular}{|c|c|c|c|c|}
\hline \multirow{2}{*}{ Group } & \multicolumn{2}{|c|}{ Boys } & \multicolumn{2}{|c|}{ Girls } \\
\hline & Spearman's R & $\mathrm{p}$ & Spearman's R & $\mathrm{p}$ \\
\hline Blind 'non-swimmers' & 0.59 & $0.000 * *$ & 0.52 & $0.000 * *$ \\
\hline Healthy 'non-swimmers' & - & - & 0.39 & $0.025 *$ \\
\hline Healthy swimmers & 0.20 & $0.045 *$ & 0.27 & $0.039 *$ \\
\hline
\end{tabular}

than the changes between the results of the second and the third measurements. They were also larger in the groups of healthy children than in the groups of blind children. In blind girls considerable lowering of the TST occurred already after 10 minutes of swimming, and in boys from that group as late as after 30 minutes of staying in the water. The results of the measurements of blind

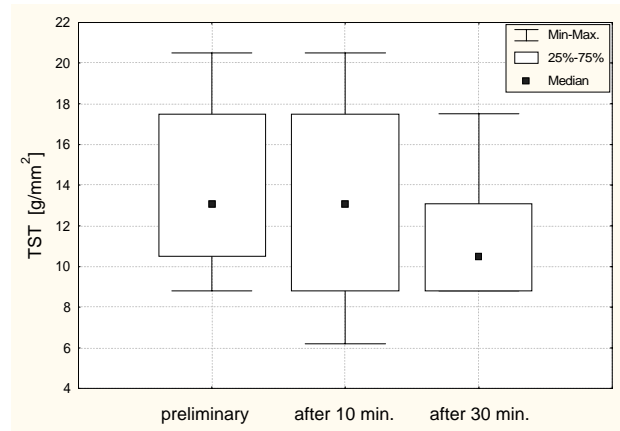

Fig. 4. Changes in TST after swimming in blind boys, swimmers.

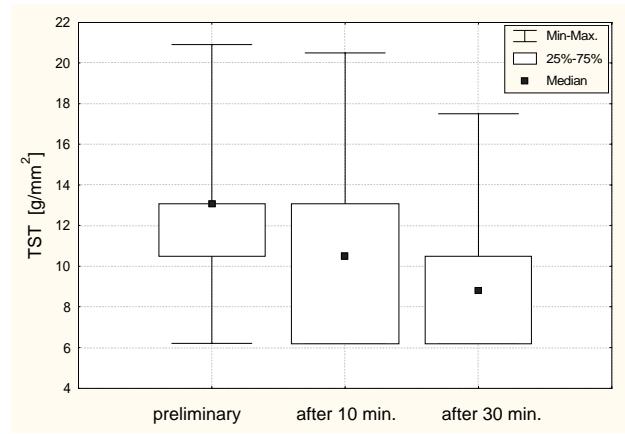

Fig. 6. Changes in TST after swimming in healthy boys, swimmers. boys who practiced swimming differed from the results for other groups by showing the smallest and the slowest TST decrease during swimming. A comparison of the distribution of the measurement results against a normal distribution model (see Figs. 1-3) indicates also that subject's staying in the water resulted in a drop in a large proportion of the TST values.

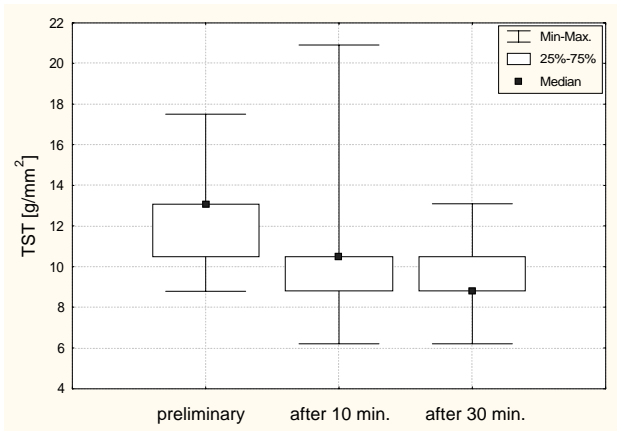

Fig. 5. Changes in TST after swimming in blind girls, swimmers.

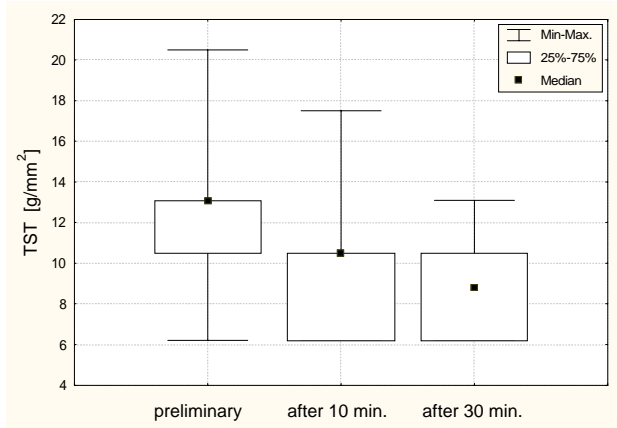

Fig. 7. Changes in TST after swimming in healthy girls, swimmers. 
Table 5. Significance of differences between the results of three subsequent measurements of swimmer subjects: 1 - taken before, 2 - 10 minutes after, and 3-30 minutes after swimming

\begin{tabular}{llccccc}
\hline \multirow{3}{*}{ Group } & \multicolumn{7}{c}{ difference between } \\
\cline { 3 - 7 } & & \multicolumn{2}{c}{$1-2-3$} & $1-2$ & $1-3$ & $2-3$ \\
\cline { 3 - 7 } & & $\chi^{2}$ & $\mathrm{p}$ & $\mathrm{p}$ & $\mathrm{p}$ & $\mathrm{p}$ \\
\hline \multirow{3}{*}{ Blind } & girls & 16.2 & $0.000^{* *}$ & $0.007^{* *}$ & $0.001^{* *}$ & 0.180 \\
& boys & 10.6 & $0.005^{* *}$ & 0.071 & $0.005^{* *}$ & 0.052 \\
& girls & 66.3 & $0.000^{* *}$ & $0.000^{* *}$ & $0.000^{* *}$ & $0.001^{* *}$ \\
& boys & 77.2 & $0.000^{* *}$ & $0.000^{* *}$ & $0.000^{* *}$ & $0.032^{*}$ \\
\hline
\end{tabular}

\section{Discussion and summary}

The results of this study only partially confirm the hypothesis on the increased tactile sensitivity of the blind or visually impaired individuals. An increased tactile sensitivity was distinct in girls but was almost non-existent in boys. A similar conclusion may be drawn from the absence of a relationship between the TST and a degree of visual impairment. Only blind subjects with normal mental development were selected for the study. However, the underdevelopment of sight might be related to the underdevelopment of other sense organs, which could have determined the results of the study. Therefore, there is a need to continue studies of tactile sensitivity of people with sight impairment and, probably, with impairment of other sense organs.

The relationships between the age of the subjects and their tactile sensitivity threshold found in the study had been indicated by other authors [VERRILLO 1993; KOZŁOWSKA 1998a,b]. The lack of age-related changes in the group of blind boys and girls who practiced swimming is nevertheless puzzling. It might indicate a modifying effect of frequent contact with water on the changeability of the trait under examination.
The differences between the results of measurements for girls and boys, visible at each stage of the result analysis are interesting. Girls who did not practice swimming, both blind and healthy, turned out to be the most sensitive subjects, while the blind boys, both swimmers and non-swimmers were the least sensitive. The greatest difference between the TST in girls and boys was in the group of the blind who did not practice swimming.

The lowering of the TST during exercise in water in subjects in all groups confirms the hypothesis on the immediate effect of staying in water environment on tactile sensitivity. However, the degree of this reaction and its development in time is not identical in all groups. The reaction of blind boys, the group with the lowest tactile sensitivity, to being in water was the weakest and the slowest one. In blind girls the lowering of the TST was also much smaller than in healthy subjects. In the latter ones the lowering of the TST during exercise in water was more substantial and occurred earlier than in the blind. The hypothesis on the permanent lowering of the tactile sensitivity threshold due to systematic contact with water environment was only confirmed in the group of blind girls, among whom the ones who practiced swimming turned 
out to be more tactilely sensitive than those who did not practice the sport. Low TST in other groups of nonswimmers compared to the groups of swimmers indicates a lack of permanent effect of frequent contacts with water occurring over the span of many years on the TST level.

The swimming exercise-related reaction of the subjects is connected not only with physical activity but also with skin hydration. BLANK [1952] noted that as a result of the contact with water hard skin of the hand palms becomes soft and more supple. In other studies [MCAULEY et al. 1993] the sense of touch of people suffering from leprosy was examined and it was found that soaking hands in water increased their tactile sensitivity.

Contact with water environment affects the epidermal water content [BLANK 1952; STENSTROM 1984] and may change the skin's physical and chemical properties [TAGAMI 1994], which in turn determines the change in tactile sensitivity [MCAULEY et al. 1993].

The effect of physical activity in aquatic environment on tactile threshold was studied in children practicing swimming [MAŚNIK and ROSTKOWSKA 2001]; the results obtained were similar to those of the current study. In all parts of the hand where the measurements were taken: the pad of the small finger, the pad of the index finger, the palm of the hand, tactile sensitivity tended to increase gradually in both boys and girls who practiced swimming, and the statistically significant difference occurred after 10 minutes of swimming. Different results were obtained from measurements taken on the forearm where initial low- ering followed by subsequent increase of tactile sensitivity was observed.

Considerable differences between the results of measurements of blind boys and girls, both in terms of the degree and reactivity of the trait under investigation, give rise to an assumption that both sexes react differently to their disability: boys by growing indifferent and by reducing their cognitive activity, while girls by triggering an adaptation mechanism, involving the replacement of the absent sight with an increased tactile sensitivity. This thesis, however, needs to be corroborated by extensive and thorough studies.

\section{Acknowledgements}

We are grateful to the Editor and the anonymous referee for many valuable comments which helped us to improve the manuscript.

\section{References}

BLANK I.H., 1952, Factors which influence the water content of the stratum corneum, J. Invest. Dermatol., 18, 432-440

Bolanowski S.J., R.T. Verrillo, 1982, Temperature and criterion effects in the somatosensory system: A neurophysiological and psychophysical study, J. Neurophysiol., 48, 837856

Elsner P., E. BerardescA, H.I. MaibaCH, 1994, Bioengineering of the skin: Water and the stratum corneum, CRC Press, Boca Raton, Florida

KozŁowsKA A., 1998a, Adaptacyjna interpretacja czucia dotyku u czlowieka, Doctoral thesis, Adam Mickiewicz University, Poznań

KozŁowsKA A., 1998b, Studying tactile sensitivity - population approach, Prz. Antropol. Anthropol. Rev., 61, 3-30

Lindsay H., D.A. Norman, 1984, Procesy przetwarzania informacji. Wstep do psychologii, PWN, Warszawa 
MAŚNIK E., E. ROSTKOWSKA, 2001, Wpływ aktywności ruchowej $w$ środowisku wodnym na progowa wrażliwość dotykowa u dzieci uprawiajacych ptywanie, [in:] Ontogeneza i promocja $z$ drowia $w$ aspekcie medycyny, antropologii $i$ wychowania fizycznego, Monografie Uniwersytetu Zielonogórskiego, Zielona Góra, (in press)

McAuley D.M., P.A. Ewino, J.K. DevasundARAM, 1993, Effect of hand soaking on sensory testing, Int. J. Leprosy, 61, 16-19

STENSTROM S.J., 1984, A study on skin humidity in leprosy patients using a new type of humidity meter, Int. J. Leprosy, 52, 10-18
TAGAMI H., 1994, Quantitative measurements of water concentration of the stratum corneum in vivo by high-frequency current, Acta Derm. Venereol., 185, 29-33

VERRILLO R.T., 1993, The effects of aging on the sense of touch, [in:] Sensory research: Papers in honor of Jozef Zawislocki, R.T. Verrillo (ed.), L. Erlbaum Assoc., Hillsdale, New York, pp. 285-298

VERRILlo R.T., S.J. Bolanowski, C.M. CheCKOSKY, F.P. MCGLONE, 1998, Effects of hydration on tactile, Somatosens. Mot. Res., 15, 93-108

\section{Streszczenie}

Celem pracy było określenie wysokości progu wrażliwości dotykowej (TST) u osób niewidomych lub o znacznym upośledzeniu narządu wzroku, uprawiających pływanie, a więc aktywność ruchową w środowisku wodnym, oraz nie uprawiających sportu i porównanie uzyskanych wyników badań z wynikami badań osób zdrowych w podobnym wieku.

Materiał badawczy stanowiły dzieci i młodzież niewidome i silnie niedowidzące oraz dzieci i młodzież zdrowa. W obu grupach badawczych wyszczególniono podgrupy uprawiające pływanie oraz nie uprawiające sportu (tab. 1). Progową wrażliwość dotykową (TST) mierzono przy pomocy estezjometru na opuszce palca wskazującego ręki dominującej. Pomiar wykonywano trzykrotnie: przed rozpoczęciem zajęć w wodzie czyli pomiar wstępny (tak zwany „na sucho”), po 10 minutach pływania i po $30 \mathrm{~min}$. pływania. W grupach, które nie ćwiczyły w wodzie, wykonywano tylko pomiar „na sucho”. Charakterystykę wyników badań podano w tabelach 2 i 3 , a przykładowe rozkłady na tle modelu rozkładu normalnego na rysunkach 1-3.

Dziewczęta niewidome wykazywały istotnie większą wrażliwość dotykową (niższy próg wrażliwości) w porównaniu $\mathrm{z}$ dziewczętami zdrowymi. U chłopców nie wystąpiła statystycznie istotna różnica pomiędzy zdrowymi a niewidomymi i niedowidzącymi. Przy porównywaniu wyników badań pomiędzy dziewczętami a chłopcami stwierdzono tylko jedną statystycznie istotną różnicę - chłopcy niedowidzący i nie pływający okazali się mniej wrażliwi dotykowo od odpowiedniej grupy dziewcząt.

Porównanie pomiędzy podgrupami uprawiającymi pływanie a nie uprawiającymi sportu wskazało także tylko na jedną różnicę. Niewidome dziewczęta $\mathrm{z}$ grupy pływających okazały się bardziej wrażliwe dotykowo niż niewidome dziewczęta z grupy nie pływających. Wyniki badań przedstawione na rysunkach 4-7 wskazują na obniżanie się TST podczas zajęć w wodzie (tab. 5). Zmiany te były większe w grupach badanych zdrowych niż w grupach dzieci niewidomych.

Brak zmian związanych z wiekiem w grupie niewidomych chłopców i dziewcząt uprawiających pływanie (tab. 4), mógłby świadczyć o modyfikującym wpływie częstego kontaktu z wodą na zmienność badanej cechy. Hipoteza o trwałym obniżeniu się progu wrażliwości dotykowej pod wpływem systematycznego przebywania w środowisku wodnym znalazła potwierdzenie tylko w grupie niewidomych dziewcząt, spośród których uprawiające pływanie okazały się bardziej wrażliwe dotykowo od nie uprawiających sportu. 